\title{
CENTER FOR SEEDING AND PROTECTION OF PLANTATION BBPPTP SURABAYA IN THE PERSPECTIVE OF FARMERS' SERVICE AND SATISFACTION
}

\author{
Supriyanto Joko, Student \\ Patiung Markus*, Wisnujati Nugrahini Susantina, Lecturers \\ Magister's Study Program of Agribusiness, Faculty of Agriculture, Wijaya Kusuma University, \\ Surabaya, Indonesia \\ *E-mail: markuspatiung@uwks.ac.id
}

\begin{abstract}
This research was conducted at the Surabaya Plantation Park Seed and Protection Center (BBPPTP). The research objectives are: (1) to analyze the value of the level of farmer satisfaction with the service performance of BBPPTP Surabaya; (2) to take inventory and analyze the extent to which the level of conformity between the performance of public services and the level of importance affects the performance of BBPPTP Surabaya services against the perspective of farmer satisfaction. Methodology, the method of determining the sample usingthe Krejcie and Morgan table; the data collection method is the interview method with the help of a questionnaire, methodsdata analysis used is Analysis of Importance Performance Analysis (IPA) and Cartesian Diagram. Research Results: (1) Overall farmers in East Java are satisfied with the services provided by BBPPTP Surabaya. (2) The results obtained show that the suitability level of the 9 attributes has not yet reached 100 percent, except for the completion time of work and infrastructure which has reached 100 percent. This can be explained that the services provided by BBPPTP Surabaya have not met all the expectations of farmers. Therefore, BBPPTP Surabaya must make continuous improvements, find out what farmers want and improve their performance so that farmers' expectations are fulfilled and satisfied. The high level of conformity is the attribute of service completion time and infrastructure, while the lowest is the attribute of handling complaints.
\end{abstract}

\section{KEY WORDS}

Analysis, performance, service, satisfaction.

According to the Regulation of the Minister of State Apparatus Empowerment No. 14 of 2017 concerning guidelines for the preparation of public satisfaction surveys (SKM) of public service administration units by government officials, currently it is felt that they have not met the expectations of the community. This can be seen from the various complaints submitted by the public through mass media and social networks. Of course, these complaints, if not handled, will have a negative impact on the government. Furthermore, it can cause distrust from the community. One of the efforts that must be made in improving public services is to carry out a community satisfaction survey of service users by measuring the satisfaction of service users.

According to Siegel and Marconi in Mulyadi (2001), Service performance appraisal is the periodic determination of the operational effectiveness of an organization, its parts of the organization, and its employees based on predetermined goals, standards and criteria. Given the importance of performance appraisal, it is necessary to conduct research on the analysis of the performance of BBPPTP Surabaya. This performance analysis is based oncustomer satisfaction perspective. Survey kcustomer satisfaction is obtained from questionnaires and interviews with farmers, while testing the community satisfaction data used in the Likert scale calculation with the community satisfaction survey method (SKM) in accordance with the Regulation of the Minister of Utilization of State Apartments and Bureaucratic Reform of the Republic of Indonesia No. Analysis (IPA) to analyze the level of satisfaction with the performance of BBPPTP Surabaya. 
According to Fornel (1992) in Aryani D. and Rosinta (2013), customer satisfaction is the key to creating customer loyalty. There are many benefits received by the company by achieving a high level of customer satisfaction, namely in addition to increasing customer loyalty but also preventing customer turnover, reducing customer sensitivity to prices, reducing marketing failure costs, reducing operating costs caused by increasing the number of customers, increasing advertising effectiveness, and improve business reputationTherefore BBPPTP Surabaya needs to prepare itself as a provider of good public services that can be seen through the services provided to farmers. In order for the performance to run well, the BBPPTP Surabaya needs to know the performance at the level of importance and satisfaction of farmers' needs. Based on this, the following problems can be formulated: (1) What is the level of farmer satisfaction with the service performance of BBPPTP in Surabaya? (2)What factors influence the level of conformity between the service performance of BBPPTP Surabaya and farmer satisfaction?

Research purposes: (1) Analyze the value of the farmer's satisfaction level on the service performance of BBPPTP Surabaya. (2) Inventory and analyze the extent to which the level of conformity between the performance of public services and the level of importance that affects the service performance of BBPPTP Surabaya on the perspective of farmer satisfaction.

\section{LITERATURE REVIEW}

According to Kurniawan (2016). The main problem of public services is basically related to the quality of the service itself. According to Chasana (2013) about public services here can be used as the most visible measure of the performance of the government. Public service (public) according to Sianipar (1998: 5) is defined as all forms of public sector services carried out by government officials, including officials engaged in the economy in the form of goods and or services, which are in accordance with the needs of the community, and the provisions of laws and regulations - valid invitations.

According to Irawan (2002) there are 5 indicators of service quality according to customers: (Tangibles, Reliability, Responsiveness, Assurance, and Emphaty). Thus service plays a very important role in maintaining consumer loyalty, as well as services provided by local governments to business people. If they feel they are not getting satisfactory service, they will immediately look for other, more competitive areas to move their business.

According to Subarsono (2008), service products in the form of goods can apply to many people. On the other hand, services received by someone do not necessarily match or equal the services received or expected by other people. The level of customer importance is defined as customer confidence before trying or buying a service product which will be used as a reference standard in assessing the performance of the service product (Rangkuti, 2006).Customer perceptions of products and services affect: the level of customer importance, customer satisfaction and customer value (Rangkuti, 2006).According to Irawan (2002), five factors determine the level of customer satisfaction (product quality, service quality, emotional factors, product price and convenience).

Supranto (2000) states that the measurement of the level of satisfaction is closely related to the quality of the product (goods or services). Measurement of quality aspects is beneficial for business leaders, including: (1) Knowing well how the business process works, (2) Knowing where to make changes in an effort to make continuous improvements to satisfy customers, especially for things that considered important by customers, (3) Determine whether the changes made lead to improvement. According to Gerson (2001) in Nugroho (2009), there are five benefits of measuring quality and customer satisfaction, namely: excellent service, performance and achievement standards, measuring implementation performance, improving quality and satisfaction, and motivation.

According to Siegel and Marconi in Mulyadi (2001), performance appraisal is the periodic determination of the operational effectiveness of an organization, its parts of the organization, and its employees based on predetermined goals, standards and criteria. Performance measurement is divided into two, namely traditional and contemporary (Hansen 
and Mowen, 1995) in Wijayanti 2011. The principles in performance measurement according to Hansen and Mowen (1995) in Mulyadi 2001 are: Consistency with company goals; Having adaptability to needs; Can measure significant activity; Easy to publish; Top-down acceptability; Used cost effective; and Served on time.

In obtaining the National Public Service Satisfaction Index, conducting a Community Satisfaction Survey requires a uniform survey method as stipulated in the Regulation of the Minister for Administrative Reform and Bureaucratic Reform Number 14 of 2017. The community satisfaction survey conducted on public service units uses indicator nine) as follows: Requirements; Systems, Mechanisms and Procedures; Turnaround time; Fees / Tariffs; Product Specifications Type of Service; Implementing Competencies; Implementing Behavior; Handling of Complaints, Facilities and Inputs; Facilities and infrastructure.

According to Runimart (2008) Importance Performance Analysis (IPA) in Anggraini L. et al. 2012, is conceptually a multi-attribute model. This technique identifies the strengths and weaknesses of market offerings by using two criteria, namely the relative importance of attributes and customer satisfaction. After determining the appropriate attributes, consumers were asked two questions. One is an attribute that stands out and the second is the performance of the company that uses these attributes. With Cartesian diagrams using mean, median or ranking measures, the scores of importance and performance attributes are collected and classified into high or low categories; then by pairing the two sets of rankings, each attribute is placed into one of the four quadrants of performance importance (Crompton and Duray, 1985 in frederik monte 2016).

Hypothesis:

- The value of the results of the community satisfaction survey (SKM), especially farmers in the working area of East Java, is considered satisfied with the performance of BBPPTP Surabaya in providing services;

- Assessment of the suitability between the level of performance and the importance of service elements is considered satisfied. Service elements that affect farmer satisfaction are service requirements, management competence, fees / rates, and facilities and infrastructure.

\section{METHODS OF RESEARCH}

The research location is the BBPPTP Surabaya Agency which is an agency engaged in seeding services and protection of plantation crops, with the consideration that farmers in several districts in East Java who often submit applications for seed certification activities and testing the quality of plantation seeds and can provide an overview of the area of one of the working areas.

The sampling technique in this study was selected by puposice which is determined according to the area coverage of each farmer who often uses services at BBPPTP Surabaya. Understanding maps using tablesand the following formula:

$$
S=\left(\lambda^{2} . N P Q\right\} /\left\{d^{2}(N-1)+\lambda^{2} . P . Q\right\}
$$

Where: $\mathrm{S}=$ number of samples; $\lambda 2$ = lamda (multiplying factor) with $\mathrm{dk}=1$, the error rate can be $1 \%, 5 \%, 10 \% ; N=$ population; $P$ (normal spread population) $=Q=0.5 ; d=0.05$ (Source: Kemenpan RB No. 14 of 2017).

The population in this study was all plantation farmers in the East Java region. Meanwhile, the samples in this study were farmers classified into 3 (three), namely (a) landowners, (b) farmer groups, (c) farmers who breed plantation seeds in several districts in East Java Province who use services. testing the quality of seeds at BBPPTP Surabaya. The samples to be selected are farmers who frequently submit requests for testing and quality control of seeds and plant protection services as well as communicating with the Surabaya BBPPTP agency. As for the sample size and population, the sample table from the theory of Krejcie and Morgan (Appendix table) was used, so that 36 farmers were found to be respondents who were considered to have represented the respondent population. 
The data collected consisted of primary and secondary data. Primary data obtained from the results of questionnaires, field observations, and interviews with farmers. In order to enrich primary data, interviews were also conducted with several respondents from other plantation agencies who often collaborate with BBPPTP Surabaya.

Assessment of the level of community satisfaction as users of BBPPTP Surabaya's public services is by listening to or collecting perceptions from respondents about farmers' satisfaction with the performance of BBPPTP Surabaya. The following elements of the customer satisfaction survey used in this study are Requirements; Systems, Mechanisms and Procedures; Turnaround time; Fees / Tariffs; Product specification type of service; Implementation competence; Implementing behavior; Handling complaints, suggestions and input; and Facilities and infrastructure ( PERMENPANRB Number 14 of 2017).

The SKM value is calculated using the "weighted average value" of each service element. In calculating the community satisfaction index for the 9 (nine) service elements studied, each service element has the same weight as the following formula:

$$
\text { Weighted average value }=\frac{\text { Jumlah Bobot }}{\text { Jumlah Unsur }}==\mathrm{N} \frac{1}{\mathrm{X}}
$$

To obtain the service unit SKM value, the weighted average value approach is used with the following formula:

$$
\text { SKM x weighting value }=\frac{\text { Total dari nilai persepsi per unsur }}{\text { Total unsur yang terisi }}
$$

To facilitate interpretation of the SKM assessment, which is 25-100, the results of the assessment above are converted to a base value of 25 , with the following formula:

\section{SKM Service Unit x 25}

Table 1 - Perception Value, SKM Interval, SKM Conversion Interval, Service Quality and Service Unit Performance

\begin{tabular}{|c|c|c|c|c|}
\hline $\begin{array}{c}\text { SCORE } \\
\text { PERCEPTION }\end{array}$ & $\begin{array}{c}\text { SCORE } \\
\text { INTERVALI } \\
\text { SKM }(\mathrm{N})\end{array}$ & $\begin{array}{c}\text { SCORE } \\
\text { INTERVAL } \\
\text { SKM CONVERSION }\end{array}$ & SERVICE QUALITY $(\mathrm{x})$ & $\begin{array}{c}\text { PERFORMANCE } \\
\text { UNIT } \\
\text { SERVICE }\end{array}$ \\
\hline 1 & $1.00-2.60$ & $25.00-64.99$ & $\mathrm{D}$ & Not good \\
\hline 2 & $2.60-3.06$ & $65.00-76.60$ & $\mathrm{C}$ & Not good \\
\hline 3 & $3.06-3.50$ & $76.61-88.30$ & $\mathrm{~B}$ & Good \\
\hline 4 & $3.53-4.00$ & $88.31-100.00$ & $\mathrm{~A}$ & Very good \\
\hline
\end{tabular}

Source: PERMENPANRB Number 14 of 2017.

Analysis using the Importance Performance Analysis (IPA) method is intended to determine the state of each variable from the satisfaction factors in terms of importance and performance. This method is also used to determine the priority improvements to the performance attributes of public services. Furthermore, for the performance appraisal of the variables of the satisfaction factor it is indicated by the letter $X$, while for the assessment of the importance factor it is indicated by the letter $Y$.There are several steps in operating the IPA method, namely: As an indicator of a quantitative measure scale for the level of importance according to community perceptions the real performance of a product is stated in a Likert scale. This scale allows respondents to be able to express the intensity of their feelings about the characteristics of policy products in public services by determining the total score of each indicator from variables $X$ and $Y$. Then multiplying all data frequencies by their weights (Simamora 2001). Measurement of the level of performance of public services, 
especially regarding the performance of farmers' interests, is used the following Likert scale; ( 1 = Not Important; 2 = Less Important; $3=$ Important; 4 = Very Important). 2 = Less Important; 3 = Important; 4 = Very Important). 2 = Less Important; 3 = Important; 4 = Very Important).

The formula for determining the scale range is as follows:

$$
\text { Scale range }=\frac{X i b-X i k}{\text { Number of measurement scales }}
$$

Where: $\mathrm{Xib}=$ The greatest possible score, assuming that all respondents give very important / very satisfied answers to every element of public service performance; Xik = the smallest possible score with the assumption that all respondents give insignificant / dissatisfied answers to every element of public service performance.

Table 2 - Scale of Interest Level of Service Unit Performance

\begin{tabular}{|c|c|c|c|}
\hline $\begin{array}{c}\text { SCORE } \\
\text { SCALE }\end{array}$ & $\begin{array}{c}\text { SCALE VALUE } \\
\text { LEVEL OF INTEREST }\end{array}$ & PERFORMANCE QUALITY $(Y)$ & $\begin{array}{c}\text { UNIT PERFORMANCE } \\
\text { SERVICE }\end{array}$ \\
\hline 1 & $40-69$ & D & Not important \\
\hline 2 & $70-99$ & C & Not too important \\
\hline 3 & $100-129$ & B & Urgent \\
\hline 4 & $130-160$ & A & Very important \\
\hline
\end{tabular}

Source: Primary data processed (2017).

Cartesian diagram (Importance-Performance Matrix) is a shape divided into four parts bounded by two lines that intersect perpendicularly at the points (Supranto, 2006). The calculation results from the use of these formulas are then entered into a Cartesian diagram, so that it is known which indicators are achievement and need to be maintained. In addition, it is also known which indicators are of poor quality and need to be prioritized for improvement. An overview of the Cartesian diagram can be seen in Figure 1.

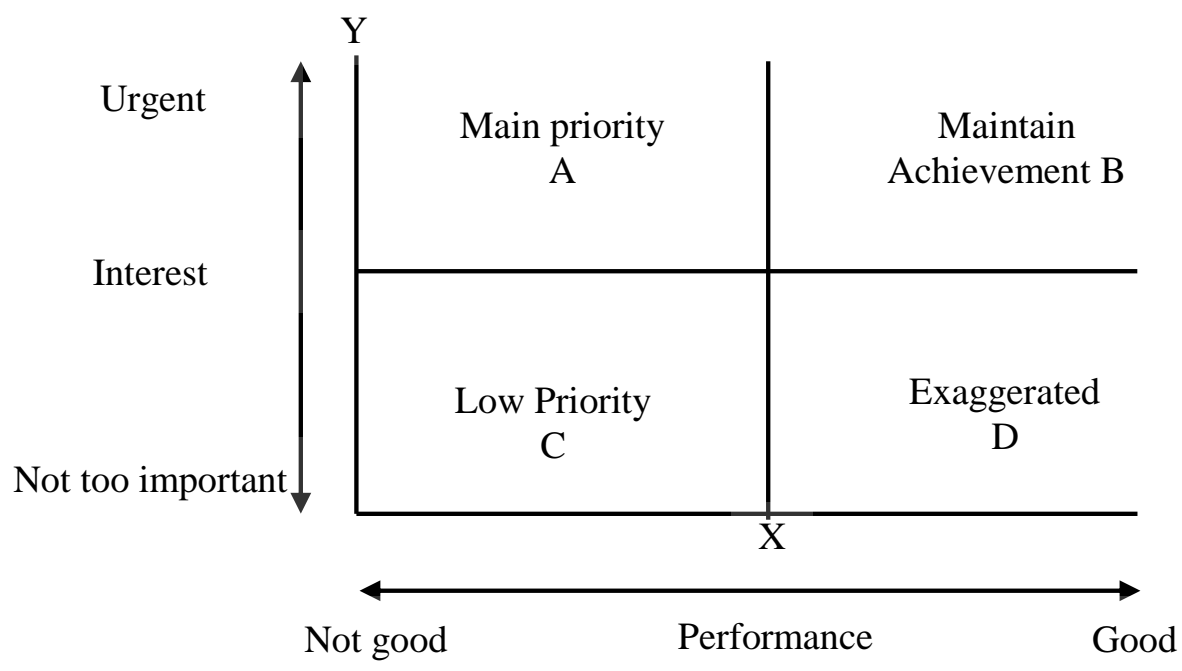

Figure 1 - Cartesian Diagram (Importance Performance Matrix)

Note: A. Shows aspects or elements that are considered to affect community satisfaction, including service elements that are considered very important, but management has not implemented them according to the wishes of the service user community. The result is disappointing not satisfied; B. Shows the main service elements that the organization / agency have successfully implemented and for that it must be maintained. Is considered very important and very satisfying; $C$. Shows some aspects that are less important for the community. The implementation by the organization was mediocre. Considered less important and less satisfying; D. Shows which aspects that affect the customer are less important, but overexerted. Considered less important but very satisfying. 


\section{RESULTS AND DISCUSSION}

To determine the fluency of the data from the responses of 36 respondents on Requirements (A); Systems, Mechanisms and Procedures (B); Turnaround time (C); Fees / Rates (D); Product specification type of service $(E)$; Implementation competence $(F)$; Implementation behavior (G); Handling complaints, suggestions and input $(\mathrm{H})$; Facilities and infrastructure (I) using the help of the computer program SPSS 21.0. The results of testing the validity of the research variables were the F-hit test: $(A)=0.403 ;(B)=0.284 ;(C)=0.396$; $(D)=0.643 ;(E)=0.628 ;(F)=0.585 ;(G)=0.537 ;(H)=0.581$; and $(I)=0.622$. while Ftab = 0.270 . This shows that the statement items on all variables are valid because the resulting pearson correlation (rcount) value is greater than 0.270 ( $r$ table).

To find out the accuracy of the data from the responses of 36 respondents about Requirements (A); Systems, Mechanisms and Procedures (B); Turnaround time (C); Fees / Rates (D); Product specification type of service $(E)$; Implementation competence $(F)$; Implementation behavior (G); Handling complaints, suggestions and input $(\mathrm{H})$; Facilities and infrastructure (I), then the reliability test is used for each variable with the help of the SPSS 21.0 program. The results of reliability testing on the research variables, the ralpha value of 0.748 , is greater than the minimum cronbanc alpha of 0.60 . So it can be concluded that the research instrument used to measure the variable can be said to be friable or reliable.

The level of farmer satisfaction is a reality received by farmers based on the performance in the form of services from BBPPTP Surabaya. The results of the analysis of the level of farmer satisfaction with the performance of the service quality attributes of BBPPTP Surabaya can be seen in Table 7.

Table 4 - Satisfaction Level of Service Requirement Attributes for Farmers at BPPTTPT Surabaya

\begin{tabular}{|l|l|l|l|}
\hline Element Code & Element & Performance & Index \\
\hline A & Terms of service & 3.44 & 86.11 \\
\hline B & Systems, mechanisms, procedures & 3.50 & 87.50 \\
\hline C & Service turnaround time & 3.69 & 92.36 \\
\hline D & Fees / Rates & 3.53 & 88.19 \\
\hline E & Products / service results & 3.44 & 85.88 \\
\hline F & Implementing competence & 3.47 & 86.81 \\
\hline G. & Implementing behavior & 3.50 & 87.50 \\
\hline H & The handling of complaints & 3.53 & 88.19 \\
\hline I & Facilities and infrastructure & 3.50 & 87.50 \\
\hline ZUsed element: & & 9.00 & \\
\hline Total & & 3.51 & 87.78 \\
\hline
\end{tabular}

Source: Primary Data Analysis.

In table 4 , it can be seen that the attribute to $C$ (service completion time), namely BBPPTP Surabaya's ability to answer questions, has the highest level of satisfaction with a value of 3.69. This shows that the performance of BBPPTP Surabaya for this attribute is already very good, so the performance on this attribute needs to be maintained. While the service attributes with the lowest level of satisfaction were attributes to A (requirements) and attributes to $E$ (products / service outcomes), namely providing terms and products / service results, as long as BBPPTP Surabaya provided services with a value of 3.44 each. This shows that the service attribute performance is not in accordance with what the farmers in the BBPPTP Surabaya work area need to improve its performance for this attribute.

The level of importance is the level of farmers' expectations for the services provided by BBPPTP Surabaya. The greater the level of farmers' expectations of BBPPTP Surabaya, the more important the service is to improve its performance. The results of the analysis of the level of importance of the service quality attributes of BBPPTP Surabaya for farmers can be seen in Table 5.

Time for completing the work has the highest average level of importance, namely 3.69. This shows that the level of importance in this attribute is very high. Farmers consider that the services provided by BBPPTP Suarabaya are very important for farmers, so that 
BBPPTP Surabaya can be more effective and efficient in delivering services to farmers. Meanwhile, the service attribute with the lowest level of importance based on the average value is complaint handling with an average value of3.33. This attribute is in the scale range is still important, but not as important as the other attributes. This means that this attribute must still be considered.

Table 5 - Level of Importance of Service Requirement Attributes for Farmers at BBPPTP Surabaya

\begin{tabular}{|l|l|l|l|}
\hline Element Code & Element & Importance & Index \\
\hline A & Terms of service & 3.39 & 84.72 \\
\hline B & Systems, mechanisms, procedures & 3.42 & 85.42 \\
\hline C & Service turnaround time & 3.69 & 92.36 \\
\hline D & Fees / Rates & 3.44 & 86.11 \\
\hline E & Products / service results & 3.38 & 84.49 \\
\hline F & Implementing competence & 3.39 & 84.72 \\
\hline G. & Implementing behavior & 3.36 & 84.03 \\
\hline H & The handling of complaints & 3.33 & 83.33 \\
\hline I & Facilities and infrastructure & 3.50 & 87.50 \\
\hline Number of Elements Used: & & 9.00 & \\
\hline Total & & 3.43 & 85.85 \\
\hline
\end{tabular}

Source: Primary Data Analysis.

The results of the calculation are obtained from the average calculation of the level of interest and level of satisfaction of farmers through distributing questionnaires, then the results obtained are mapped into a Cartesian diagram. After being mapped, it will be seen how the performance of BBPPTP Surabaya towards its service attributes and can provide information whether it still needs to make improvements or maintain its performance. The calculation of the average score for the level of importance and performance of BBPPTP Surabaya can be seen in Table 6.

Table 6 - IPA Combined Value

\begin{tabular}{|l|l|l|l|}
\hline Element Code & Element & Value_X & Value_Y \\
\hline A & Terms of service & 3.44 & 3.39 \\
\hline B & Systems, mechanisms, procedures & 3.50 & 3.42 \\
\hline C & Service turnaround time & 3.69 & 3.69 \\
\hline D & Fees / Rates & 3.53 & 3.44 \\
\hline E & Products / service results & 3.44 & 3.38 \\
\hline F & Implementing competence & 3.47 & 3.39 \\
\hline G. & Implementing behavior & 3.50 & 3.36 \\
\hline H & The handling of complaints & 3.53 & 3.33 \\
\hline I & Facilities and infrastructure & 3.50 & 3.50 \\
\hline & Average & 3.51 & 3.43 \\
\hline
\end{tabular}

Source: Primary Data Analysis.

Based on the Table 6 it can be seen that the average value for the level of importance is 3.43. The attributes whose importance value is above the average are 4 attributes, while for the satisfaction level the average value is 3.51 . There are 2 attributes whose satisfaction score is above the average.

The results of the measurement of these service elements are based on their level of importance and performance which allows BBPPTP Surabaya to make improvements to attributes that are really considered important by farmers in order to satisfy them. To be able to see the position of the data placement that has been analyzed, it can be divided into four quadrants which can be seen in Figure 2, to obtain the points on the matrix.

From the results of the quadrant analysis using the Cartesian diagram in Figure 2, the attributes that affect farmer satisfaction in East Java Province are divided into four parts, namely quadrant A (top priority), quadrant B (maintain achievement), quadrant C (low priority), and quadrant $\mathrm{D}$ (excess). 


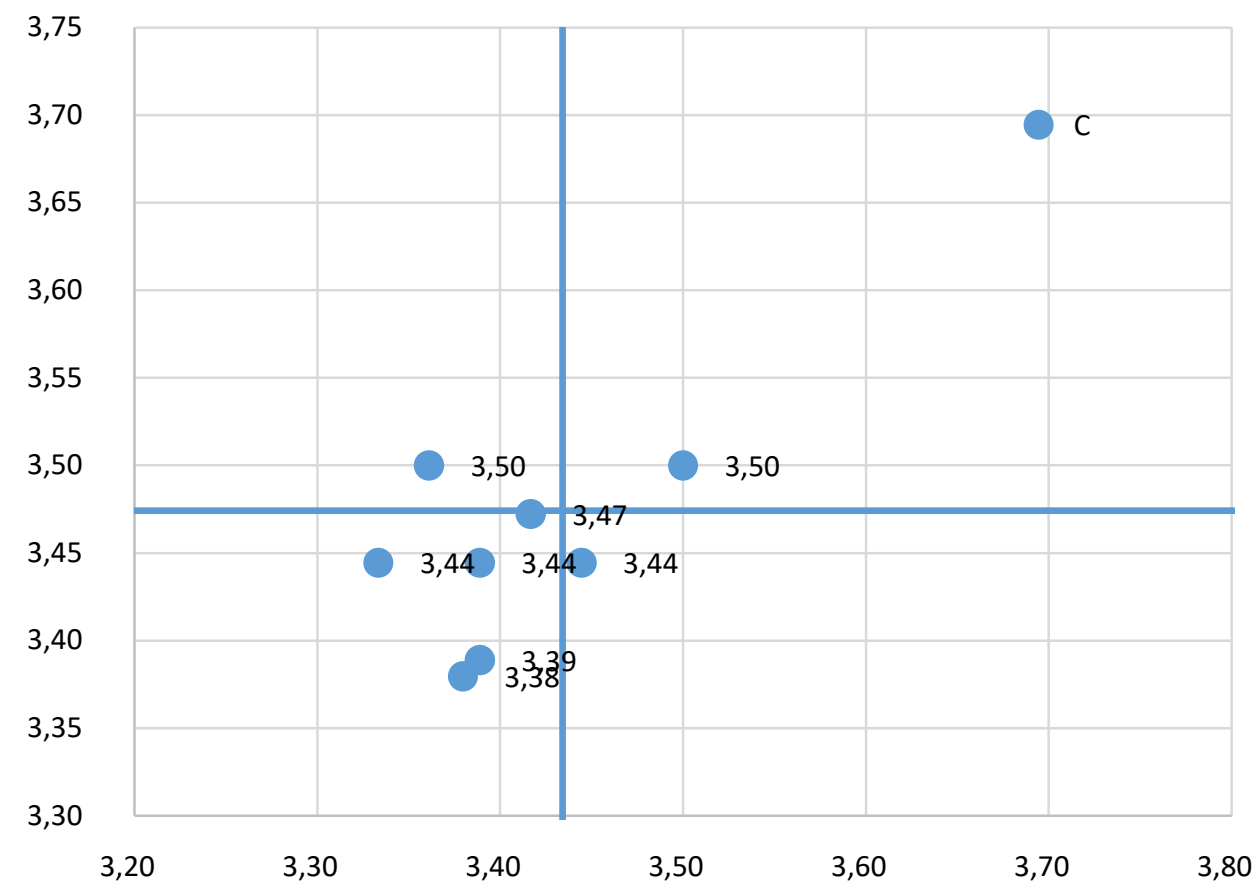

Figure 2 - Cartesian diagram

Quadrant A Improve Performance. In this quadrant, farmers feel that the existing service attributes are considered important, but in fact these attributes are not in accordance with their satisfaction, so the performance of BBPPTP Surabaya must seek adequate resources to improve performance on these various attributes. The attributes include: $G$ (Behavior). The attributes that are located in this quadrant are the main priority to improve their performance so that farmer satisfaction can be increased.

Quadrant B Maintain Performance. The attributes located in this quadrant are considered as supporting factors for farmer satisfaction. This means that if BBPPTP Surabaya can maintain its performance on things that are considered important and become the hope of farmers, then this can increase farmers' satisfaction with BBPPTP Surabaya services so that BBPPTP Surabaya is obliged to maintain the achievements that have been achieved. The attributes located in this quadrant include: C (completion time) and I (facilities and infrastructure).

Low Priority Quadrant $C$. This means that in this quadrant farmers do not consider it important and have not felt satisfaction with the service attributes provided, so that BBPPTP Surabaya does not need to prioritize or pay too much attention to these attributes, it is enough just to maintain and adjust to current conditions. These attributes include D (Cost / Tariff) It is easy for farmers to get cheap services according to their abilities.

The $D$ Quadrant Tends To Be Excessive. This quadrant explains that farmers feel that the existing attributes are considered satisfactory, but not too important by farmers so that BBPPTP Surabaya does not need to allocate too much resources related to these attributes, it is enough just to maintain the attributes included in this quadrant are A (Requirements), $B$ (System, Mechanism and Procedure), E (Product specification type of service), F (Competency implementation), $\mathrm{H}$ (Handling of complaints, suggestions and input).

The analysis of the level of suitability of 9 service attributes of BBPPTP Surabaya is in Table 7. The results obtained show that the suitability level of the 9 attributes has not reached 100 percent, except for the completion time of work and infrastructure which has reached 100 percent. This can be explained that the services provided by BBPPTP Surabaya have not met all the expectations of farmers. Therefore, BBPPTP Surabaya must make continuous improvements, find out what farmers want and improve their performance so that farmers' expectations are fulfilled and satisfied. 
Table 7 - Service Attribute Suitability Level AnalysisBBPPTP Surabaya

\begin{tabular}{|l|l|l|l|l|l|}
\hline No. & Attribute & Weight of Importance & Satisfaction Level Weight Level of Conformity & Priority \\
\hline A & Terms of service & 84.72 & 86.11 & 98.39 & 7 \\
\hline B & Systems, & 87.50 & 97.62 & 2 \\
& procedures & & & \\
\hline C & Service turnaround time & 85.42 & 92.36 & 100.00 & 8 \\
\hline D & Fees / Rates & 82.36 & 88.19 & 97.64 & 3 \\
\hline E & Products / service results & 86.11 & 85.88 & 98.38 & 6 \\
\hline F & Implementing competence & 84.49 & 86.81 & 97.59 & 4 \\
\hline G. & Implementing behavior & 84.03 & 87.50 & 97.70 & 5 \\
\hline H & The handling of complaints & 83.33 & 88.19 & 94.49 & 1 \\
\hline I & Facilities and infrastructure & 87.50 & 87.50 & 100.00 & 8 \\
\hline & Total & & 97.98 & \\
\hline
\end{tabular}

Source: Appendices 2 and 3, 2018.

The analysis of the level of suitability can also be ranked based on the score obtained from the calculation and the ranking starts from the lowest to the highest. The rank of this suitability level can be used by BBPPTP Surabaya to find out the priority order of efforts to improve and improve the service quality of BBPPTP Surabaya so that BBPPTP Surabaya can maintain its performance and make continuous improvements, so that farmers' expectations can be fulfilled as a whole.

Based on Table 7, the attributes that have the highest level of suitability, namely the attribute time of completion of services and infrastructure at 100 percent each, meaning that the performance carried out by BBPPTP Surabaya meets the expectations of farmers, namely 100 percent. Meanwhile, the attribute of handling complaints from farmers has the lowest level of conformity, which is 94.49 percent. This shows that the services provided by BBPPTP Surabaya are not in accordance with the expectations of farmers in the work area of BBPPTP in Surabaya because handling complaints is very dependent on central policy, BBPPTP Surabaya can only assist in submitting submissions to the Central Government, this is a top priority for improving service quality at BBPPTP Surabaya.

\section{CONCLUSION}

Overall farmers in East Java are quite satisfied with the services provided by BBPPTP Surabaya. The high level of suitability is the attribute of service completion time and infrastructure, while the lowest is the attribute of handling complaints.

Suggestions:

- It is better if BBPPTP Surabaya conducts monitoring and evaluation intensively on the performance of BBPPTP Surabaya to maintain the effectiveness of service activities;

- It is hoped that farmers can cooperate with BBPPTP Surabaya and participate in service activities to increase farmers' knowledge.

\section{REFERENCES}

1. Agus Dwiyanto, editor. Yogyakarta (ID): Gadjah Mada University Press.

2. Alida Palilati 2014, "The Effect of Satisfaction Levels on Customer Loyalty in Banking Savings in the Bugis Region", Journal of Social Sciences, pp. 65- 74.

3. Aryani D and Rosinta F, 2010. The Effect of Service Quality on Customer Satisfaction in Forming Customer Loyalty. Journal of Administrative and Organizational Sciences Vol 17 No 2 ISSN 0854-3844.

4. Anggraini L, et al 2012. Analysis of Consumer Perceptions using the Importance Performance analysis method and customer satisfaction Index Journal Industri Vol 4 No 2 Pages $74-81$.

5. BBPPMBTPH, 2010. Quality Testing of Food Crops and Horticulture Seeds. Directorate General of Food Crop Production Development. 
6. Chasanah, U. 2013. Performance Measurement Based on Community Satisfaction Index at Kalirungkut Health Center Surabaya, Journal of Accounting Science and Research Vol. 2, No.3.

7. Irawan, 2002 Customer Satisfaction. http: // thesis -management. blogspot. com / 2011/03 / factors-influencing-customer-satisfaction.html.

8. Kurniawan, CR 2016. Quality Innovation of Local Government Public Service. Journal of the Quality of Local Government Public Services. Faculty of Government Science and Science, University of Lampung.

9. Mulyadi. 2001. Balanced Scorecard: A Contemporary Management Tool for Multiplying Corporate Financial Performance. Salemba Empat, Jakarta.

10. Mulyadi and J. Setyawan. 2001. Corporate Planning and Control Systems. Second Edition. Salemba Publisher Four. Jakarta.

11. Nugraha.AA 2009. Analysis of Customer Satisfaction Levels of Tirta Pakuan Regional Drinking Water Company (PDAM) Bogor City in East Bogor District.

12. Regulation of the Minister of State Apparatus Empowerment No. 14 of 2017 concerning guidelines for preparing community satisfaction surveys (SKM).

13. Rangkuti, F. 2006. Measuring Customer Satisfaction. PT Gramedia Pustaka Utama. Jakarta.

14. Subarsono AG. 2008. Realizing Good Governance through Public Services.

15. Supranto, 2000. The Effect of Customer Satisfaction to Increase Market Share. Rineka Cipta. Jakarta.

16. Sianipar. 1998. Community Service Management. Jakarta: State Administration Institute.

17.Wikipedia, 2008. Public service. ttps: //id.wikipedia.org/wiki/UndangUndang_Open_Public_Information. 